\title{
LARGE SCALE TESTS OF BOULDER CLAY EROSION AT THE WIERINGERMEER DIKE (IJSSELMEER)
}

\author{
Guido Wolters ${ }^{1}$, Jan-Willem Nieuwenhuis ${ }^{2}$, Jentsje van der Meer $^{3}$ and \\ Mark Klein Breteler ${ }^{4}$
}

\begin{abstract}
A large scale model investigation (scale 1:1) of the erosion resistance of boulder clay in dikes under wave attack was carried out in the Delta Flume of Deltares|Delft Hydraulics. The investigation showed that boulder clay has considerable erosion resistance, indicating that the Wieringermeer dike can withstand extreme storm conditions, at least several hours, after the stone revetment has been damaged. However, depending on the location of the dike section, the local wave conditions for safety assessment and the thickness of the boulder clay layer, the remaining strength is not always large enough to meet the assessment conditions without the additional protection of a toe berm and/or a revetment. The investigation indicates that the erosion resistance of boulder clay could be taken into account in the safety assessment of dikes.
\end{abstract}

\section{INTRODUCTION}

Dutch dikes are typically tested every five years on their safety. The latest assessment showed that a part of the dikes along the IJsselmeer does not meet the safety criteria anymore. The dikes in that particular section have a core of boulder clay and a revetment of natural pitched stone blocks. At the Wieringermeer dike the latter have deteriorated over the last years. The dike is further characterised by a stone berm of varying thickness up to a height of $+0.5 \mathrm{~m}$ NAP (Normal Amsterdam Datum $\approx$ MSL) which lies in front of the dike. The goal of the study was to investigate if the boulder clay core still provides sufficient erosive resistance when the revetment has completely failed without necessity of refurbishment.

The core material, boulder clay (in the Netherlands termed keileem), is a material consisting of large fractions of clay, silt, sand and, to a lesser degree, shingle. It has a high density of approximately $\rho_{\mathrm{kl}}=2000 \mathrm{~kg} / \mathrm{m}^{3}$ and a low permeability. Previous field experience (INFRAM, 2005) indicates that boulder clay can have a considerable erosion resistance even after the revetment has failed.

Since previous studies were conducted at varying model scales, they have always been affected by model effects. It was therefore decided to investigate

\footnotetext{
${ }^{1}$ Department Coastal Structures \& Waves, Deltares | Delft Hydraulics, P.O. Box 177, 2600 MH Delft, The Netherlands

${ }^{2}$ ARCADIS Nederland B.V., P.O. Box 220, 3800 AE Amersfoort, The Netherlands

${ }^{3}$ Van der Meer Consulting, P.O. Box 423, 8440 AK Heerenveen, The Netherlands

${ }^{4}$ Department Coastal Structures \& Waves, Deltares | Delft Hydraulics, P.O. Box 177, 2600 MH Delft, The Netherlands
} 
the erosion resistance of the dike at a scale of 1:1 in a large scale model investigation conducted in the Delta Flume of Delft Hydraulics. For the erosion tests a section of the Wieringermeer dike was excavated and installed in the Delta Flume (without revetment) where it was exposed to wave conditions typical for the IJsselmeer.

\section{BOULDER CLAY (KEILEEM)}

Boulder clay is a clay-like material which has been employed in dikes since the 1920s. In contrast to modern dikes was the clay-like material not only used for a thin cover layer, in order to prevent water ingression, but also formed a substantial part of the core material of the dike.

Boulder clay consists of varying fractions of clay, silt and sand with pieces of shingle. The high gradation ensures a high density of approximately $\rho_{\mathrm{kl}}=$ $2000 \mathrm{~kg} / \mathrm{m}^{3}$ and a low water permeability. In its characteristics it can be compared to boulder clay. Recent literature studies (e.g. GeoDelft 2006, INFRAM 2005, LGM 1985) indicate that boulder clay has more erosion resistance than current assessment methods take account of. During the construction phase of the Wieringermeer dike for example the unprotected boulder clay dike was able to withstand flow velocities of $3-3.5 \mathrm{~m} / \mathrm{s}$ without failure.

However, boulder clay seems to be sensitive to any kind of disturbance or dynamic loading, which can undermine its shear (strength) significantly. This is mainly caused by its high sand fraction (in contrast to clay). By compaction and the passing of time lost strength can again be regained. For more information on the material properties of boulder clay in general and the investigated material from the Wieringermeer dike reference is made to Delft Hydraulics (2007), GeoDelft (2006) and Fugro (2005).
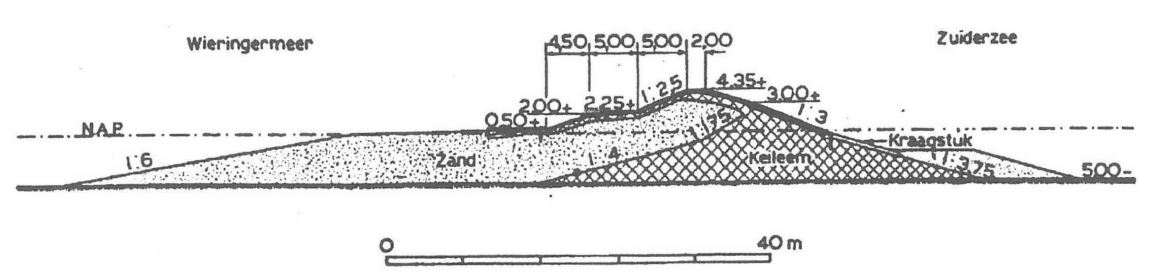

Figure 1. Cross section of the Wieringermeer dike (IJsselmeer).

\section{EXCAVATION PROCESS}

The large scale tests were conducted at a scale of 1:1 in the Delta Flume of Delft Hydraulics. The installed dike section was directly taken out of the old Wieringermeer dike, next to a section blasted during the second World War but 
which has no water defensive purpose anymore. The material was transported in blocks of 10 ton and installed in the Delta Flume, see Figures 2 and 3. The tests were conducted without revetment in order to test the erosive strength of the boulder clay material alone. After the tests the excavated section of the Wieringermeer was restored and vegetated.
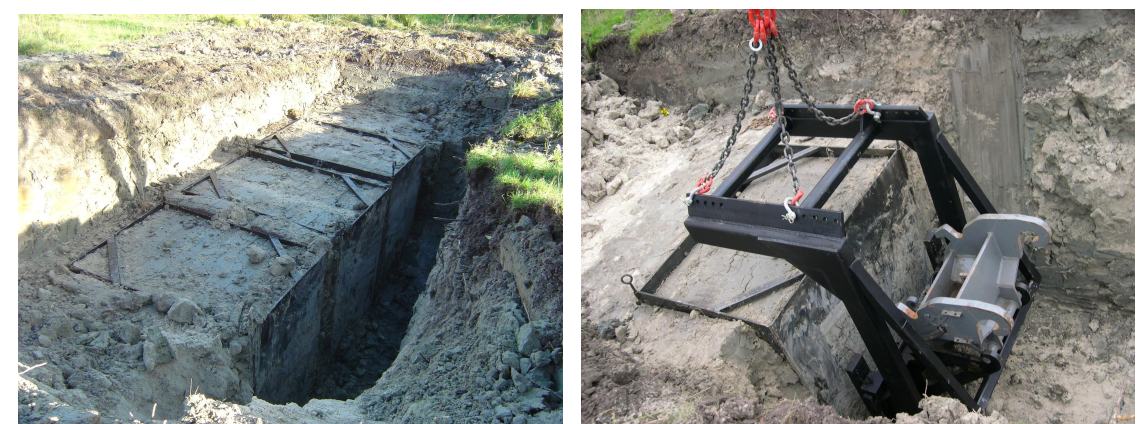

(a) Boulder clay blocks with supporting framework (b) Lifting of boulder clay blocks Figure 2. Excavation process at the Wieringermeer dike.

Before excavation the top layer of the dike (disturbed gras/root layer of $1 \mathrm{~m}$ thickness) was removed. 35 boulder clay blocks of $1.8 \mathrm{~m} \times 1.3 \mathrm{~m} \times 1.6 \mathrm{~m}$ were carefully cut out of the old dike using rectangular, at the bottom sharpened metal frames (low friction between steel sheets and soil), which were slowly pushed (not vibrated) into the dike after each other, see Figure 2. In this manner the block was incased in sheets of metal. Then the ground around the sheets was excavated, a pointed plate pushed beneath the block and the block lifted by a pallet fork out of its position. Between blocks sufficient distance was kept to ensure that excavation work did not disturb the quality of the next blocks. The above described process guaranteed that the disturbance of the boulder clay material was kept to a minimum during excavation and transport. The maximum deformation of the blocks was about $3-5 \mathrm{~cm}(<0.5 \%$ strain). Each blok weighed about 10 ton. After excavation the boulder clay blocks were kept wet and protected from desiccation by a plastic cover. The excavation of the boulder clay blocks and their installation in the testing facility were conducted simultaneously to ensure that the blocks did not have too long resting/settling periods before installation. The methodology of the excavation and installation process in the Delta Flume of Delft Hydraulics is described in more detail in Delft Hydraulics (2007). 


\section{MODEL SET-UP IN THE DELTA FLUME}

\section{Test location}

The testing location was the 240m long Delta Flume of Delft Hydraulics. The flume is $5 \mathrm{~m}$ wide and $7 \mathrm{~m}$ deep. Water depths of 1 to $5.5 \mathrm{~m}$ are possible. The maximum realizable significant wave height in the facility is $\mathrm{H}_{\mathrm{s}} \approx 1.7 \mathrm{~m}$ (irregular). Wave periods of 1-12s can be realized depending on water depth. Wave energy spectra can be prescribed by using standard or non-standard spectral shapes or by a specific time-series of wave trains. The wave board is equipped with second order steering and an active reflection compensation (ARC) system. This means that the motion of the wave board compensates for the reflected waves preventing them to re-reflect towards the model.

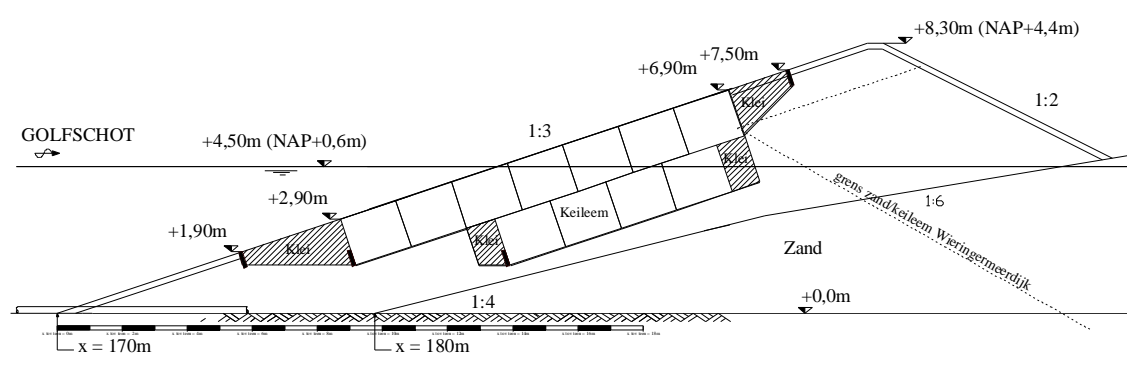

Figure 3. Model set-up in the Delta Flume of Delft Hydraulics.

\section{Model installation}

The major dimensions and features of the set-up are listed below:

- Length and width of the installed boulder clay layer in the Deltagoot: 12,6 $\mathrm{m} \times 3,9 \mathrm{~m}$.

- Maximum thickness of the boulder clay layer: $3 \mathrm{~m}$ (horizontal thickness: 7 $\mathrm{m})$.

- Length, width and height of the individual boulder clay blocks: 1,8 m x 1,3 $\mathrm{m} \times 1,6 \mathrm{~m}$.

- Boulder clay density: $2090 \mathrm{~kg} / \mathrm{m}^{3}$

- Surface level in respect to water level: from $-1,6 \mathrm{~m}$ to $+2,4 \mathrm{~m}$.

- The slope from the channel bottom up to a level of $+1.9 \mathrm{~m}$ and beyond $+7.5 \mathrm{~m}$ was made of concrete. Between $+1.9 \mathrm{~m}$ and $+2.9 \mathrm{~m}$ and from $+6.9 \mathrm{~m}$ to $+7.5 \mathrm{~m}$ compacted clay was installed. The core of the model was made of sand.

- $\quad$ Slope 1:3.

- Crest level: $+8,3 \mathrm{~m}$ in respect to the bottom of the wave channel

- Horizontal floor: no influence of shoaling was modelled/expected.

- Water level during testing: $4.5 \mathrm{~m}(\mathrm{NAP}+0.6 \mathrm{~m})$ 
- Permanent water level between tests: $+1.4 \mathrm{~m}$ (to prevent desiccation of boulder clay blocks). A higher water level was not used to avoid liquefaction of the boulder clay.

The placement of the 10ton boulder clay blocks was performed with a hydraulic crane. Hydraulic pumps were used to push each block into position and to close any remaining gaps between individual blocks. At the time of testing all joints between blocks had disappeared and the natural cohesion of the material had been mostly restored (as far as could be told). After installation the boulder clay blocks were kept moist and were covered with plastic to prevent desiccation. The boulder clay was left to rest for about 4 weeks within the channel before the actual testing started. In this fashion the boulder clay could regain much of its strength which was lost during transport.

\section{TESTING PROGRAMME}

The testing programme is given in Table 2. The following symbols are used:

$\mathrm{H}_{\mathrm{m} 0}=$ significant wave height $(\mathrm{m})$

$\mathrm{T}_{\mathrm{p}}=$ peak wave period (s)

$\mathrm{s}_{\mathrm{op}}=\mathrm{H}_{\mathrm{m} 0} /\left(1,56 \mathrm{~T}_{\mathrm{p}}^{2}\right)=$ wave steepness $(-)$

$\xi_{\mathrm{op}}=\tan \alpha / \sqrt{ }\left(\mathrm{s}_{\mathrm{op}}\right)=$ surf similarity parameter (-)

\begin{tabular}{|l|l|l|l|l|l|l|}
\hline \multicolumn{7}{|c|}{ Table 1. Test programme, water depth $=\mathbf{4 . 5} \mathbf{~ m}$} \\
\hline $\begin{array}{l}\text { Test } \\
\text { no. }\end{array}$ & $\begin{array}{l}\text { Duration } \\
\text { (hours) }\end{array}$ & $\begin{array}{l}\text { Cum. duration } \\
\text { (hours) }\end{array}$ & $\begin{array}{l}\mathrm{H}_{\mathrm{m}} \\
(\mathrm{m})\end{array}$ & $\begin{array}{l}\mathrm{T}_{\mathrm{p}} \\
(\mathrm{s})\end{array}$ & $\begin{array}{l}\text { Sop } \\
(-)\end{array}$ & $\begin{array}{l}\xi_{\text {op }} \\
(-)\end{array}$ \\
\hline 1 & 0,50 & 0,50 & 1,12 & 4,97 & 0,029 & 1,96 \\
2 & 0,82 & 1,31 & 1,17 & 5,01 & 0,030 & 1,93 \\
3 & 1,00 & 2,31 & 1,51 & 5,73 & 0,029 & 1,94 \\
4 & 1,24 & 3,55 & 1,56 & 5,77 & 0,030 & 1,93 \\
5 & 1,68 & 5,23 & 1,58 & 5,72 & 0,031 & 1,90 \\
\hline
\end{tabular}

The first 4 tests were conducted with a TMA spectrum (characteristic for the IJsselmeer), whereas the remainder was conducted with a JONSWAP spectrum to ensure that the maximum wave height of $\mathrm{H}_{\mathrm{m} 0}=1.6 \mathrm{~m}$ could be reached. After each test the water level was lowered to $+1.9 \mathrm{~m}$ until testing started on the following day. The tests were conducted in January 2007 at temperatures between 5 and $10^{\circ} \mathrm{C}$.

The wave induced erosion of the boulder clay slope was documented using a mechanical profiler. 3 longitudinal profiles were taken after each test and averaged to provide the mean profile. 


\section{RESULTS}

\section{Observations}

During testing it was observed that the erosion occurred mainly in horizontal direction, the erosion depth increased only gradually. The first 10 minutes of testing caused strong erosion. Individual waves were observed to quarry large chunks of boulder clay out of the slope (resulting in a horizontal erosion length of $1.1 \mathrm{~m}$ with an erosion depth of $0.3 \mathrm{~m}$ ). Most of the erosion was found just beneath the waterline. After the first 10 minutes the erosion visibly slowed. The starting erosion revealed stones of $5-15 \mathrm{~cm}$ diameter which were embedded in the boulder clay and a large quantity of roots was also revealed. These can have a destabilizing effect on the boulder clay and can reduce the erosion strength. The increase in wave height in test $3\left(\mathrm{H}_{\mathrm{m} 0}=1.5 \mathrm{~m}\right)$ caused a renewed increase in erosion and renewed quarrying of boulder clay blocks out of the slope. The maximum cumulative (horizontal) erosion length found after testing was $\mathrm{E}_{\mathrm{x}} \approx 5,4 \mathrm{~m}(\sim 0,3 \mathrm{~m}$ beneath the water level, see Figure 5) and the maximum cumulative erosion depth (measured vertically) was $\sim 1,9 \mathrm{~m}$.
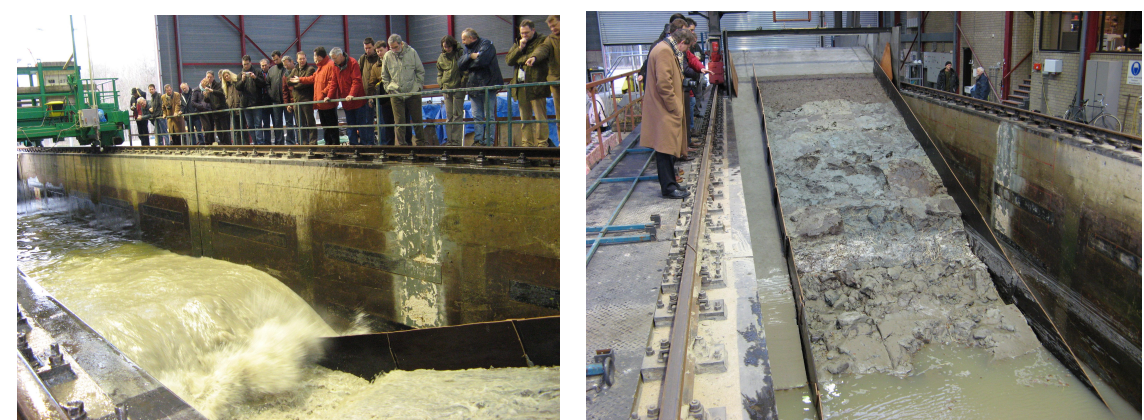

Figure 4. (a) Testing of Wieringermeer dike section in the Delta Flume. (b) Erosion profile after testing.

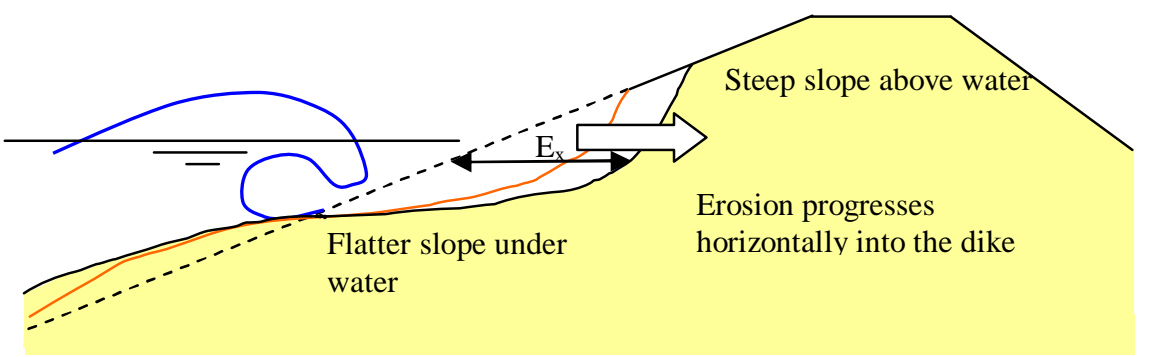

Figure 5. Schematic representation of erosion process in the horizontal direction. 
Further observations:

- During the erosion process no boundary effects were observed regarding the joints between the boulder clay blocks. The erosion occurred uniformly over the entire block independent of the joints which were barely visible anymore. This is in contrast to earlier tests by Skafel en Bishop (1994)

- Locally restricted holes of a depth of up to $0.7 \mathrm{~m}$ (especially at water level) were found in the boulder clay slope. These could have been caused by embedded sand lenses.

- The erosion occurred mainly in horizontal direction. The erosion depth remained relatively limited.

- The erosion process was characterized by "quarrying" (erosion by pulling out chunks of clay) and "abrasion" (surface erosion by scraping), see e.g. Carter and Guy (1988) for a description of the processes. The quarrying process was however dominant, causing the removal of blocks of up to $0.5 \mathrm{~m}$ diameter $\left(\sim 0,2 \mathrm{~m}^{3}\right)$. This accelerated temporarily the erosion process.

- The erosion process was increased by the formation of large fissures in the boulder clay slope which initiated the breaking off and removal of large boulder clay blocks.

- The form of the initial damage seemed to be of no relevance for the ultimate erosion length

- The speed of erosion over the entire slope was on average $28 \mathrm{~cm} /$ hour in the vertical direction (measured vertically) and $83 \mathrm{~cm} /$ hour in the horizontal direction. The measured erosion is thus of the same order of magnitude as the previously measured vertical erosion of clay: 10 à 50 $\mathrm{cm} /$ hour $\left(\mathrm{H}_{\mathrm{m} 0}=1,5 \mathrm{~m}, \mathrm{~T}_{\mathrm{p}}=5 \mathrm{~s}\right.$, Delft Hydraulics \& GeoDelft 1993a).

- The proportion of sand and clay and the shear strength seems to determine in a significant manner the erosive strength of boulder clay.

- The vertical wave loading and the missing toe armour (as present at the Wieringmeer) made the results conservative. On the other hand it must be considered that the initial erosion of the top layer could be faster in nature, since the material in situ is disturbed by desiccation and fissures. Furthermore some variation in boulder clay quality and thickness can be expected along the dike. 

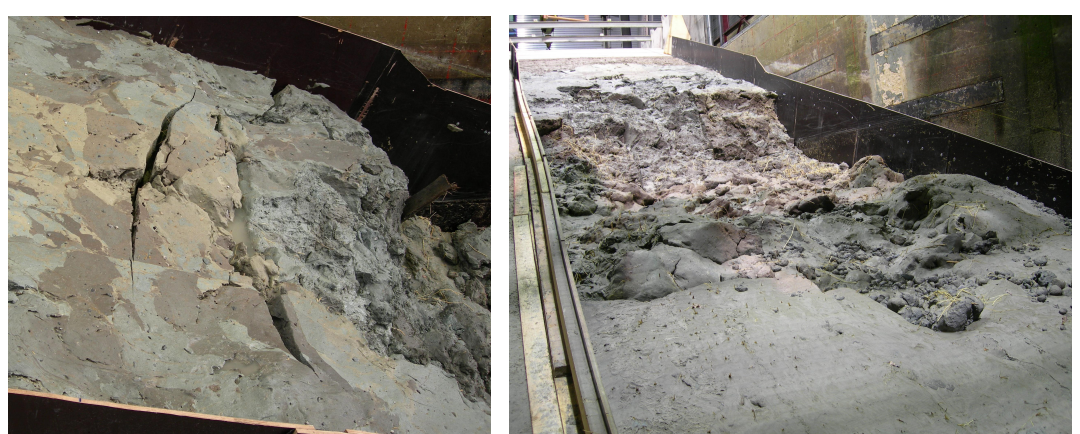

Figure 6. (a) Formation of large fissures in the boulder clay slope (b) Erosion profile development .

\section{Erosion measurements}

The actual test results for the varying wave conditions are summarized in Table 3, where $E_{x}$ is the maximum horizontal erosion length which was consistently found $0.1-0.3 \mathrm{~m}$ beneath the water level.

In Table 4 the equivalent test durations are given for a constant wave height of $\mathrm{H}_{\mathrm{m} 0}=1.6 \mathrm{~m}$, together with the maximum measured horizontal erosion. The erosion profiles, averaged over the width of the channel, can be seen in Figure 7. Figure 7 clearly shows that the erosion profile has become flatter over time whereas the erosion front has become much steeper (cliff).

\begin{tabular}{|l|l|l|l|l|l|l|}
\hline \multicolumn{7}{|l|}{ Table 3. Overview of test results. } \\
\hline Test & $\mathrm{H}_{\mathrm{m}}$ & $\mathrm{T}_{\mathrm{p}}$ & $\begin{array}{l}\text { Test } \\
\text { duration }\end{array}$ & $\begin{array}{l}\text { Cumulative } \\
\text { duration }\end{array}$ & $\begin{array}{l}\mathrm{E}_{\mathrm{x}} \text { of most } \\
\text { eroded row }\end{array}$ & $\begin{array}{l}\mathrm{E}_{\mathrm{x}} \text { of averaged } \\
\text { row }\end{array}$ \\
\hline & $\mathrm{m}$ & $\mathrm{s}$ & hour & hour & $\mathrm{m}$ & $\mathrm{m}$ \\
\hline 1 & 1,12 & 4,97 & 0,50 & 0,50 & 1,06 & 0,67 \\
2 & 1,17 & 5,01 & 0,82 & 1,31 & 2,19 & 1,53 \\
3 & 1,51 & 5,73 & 1,00 & 2,31 & 2,54 & 2,12 \\
4 & 1,56 & 5,77 & 1,24 & 3,55 & 3,57 & 2,98 \\
5 & 1,58 & 5,72 & 1,68 & 5,23 & 5,03 & 4,67 \\
6 & 1,57 & 5,98 & 0,74 & 5,98 & 5,40 & 5,14 \\
\hline
\end{tabular}

\begin{tabular}{|c|c|c|c|c|c|c|}
\hline \multirow[t]{2}{*}{ Test } & \multirow{2}{*}{$\mathrm{H}_{\mathrm{m} 0}$} & \multirow{2}{*}{$T_{p}$} & \multirow{2}{*}{$\begin{array}{l}\text { Measured } \\
\text { duration }\end{array}$} & \multicolumn{2}{|c|}{$\begin{array}{l}\text { Equivalent test duration for } \\
H_{m 0}=1,6 \mathrm{~m}\end{array}$} & \multirow{2}{*}{$\begin{array}{l}\text { measured } E_{x} \\
\text { of most } \\
\text { eroded row }\end{array}$} \\
\hline & & & & per test & cumulative & \\
\hline & $\mathrm{m}$ & $s$ & hour & hour & $\mathrm{m}$ & $\mathrm{m}$ \\
\hline 1 & 1,12 & 4,97 & 0,50 & 0,29 & 0,29 & 1,06 \\
\hline 2 & 1,17 & 5,01 & 0,82 & 0,51 & 0,80 & 2,19 \\
\hline 3 & 1,51 & 5,73 & 1,00 & 0,92 & 1,72 & 2,54 \\
\hline 4 & 1,56 & 5,77 & 1,24 & 1,20 & 2,91 & 3,57 \\
\hline 5 & 1,58 & 5,72 & 1,68 & 1,65 & 4,56 & 5,03 \\
\hline 6 & 1,57 & 5,98 & 0,74 & 0,72 & 5,29 & 5,40 \\
\hline
\end{tabular}




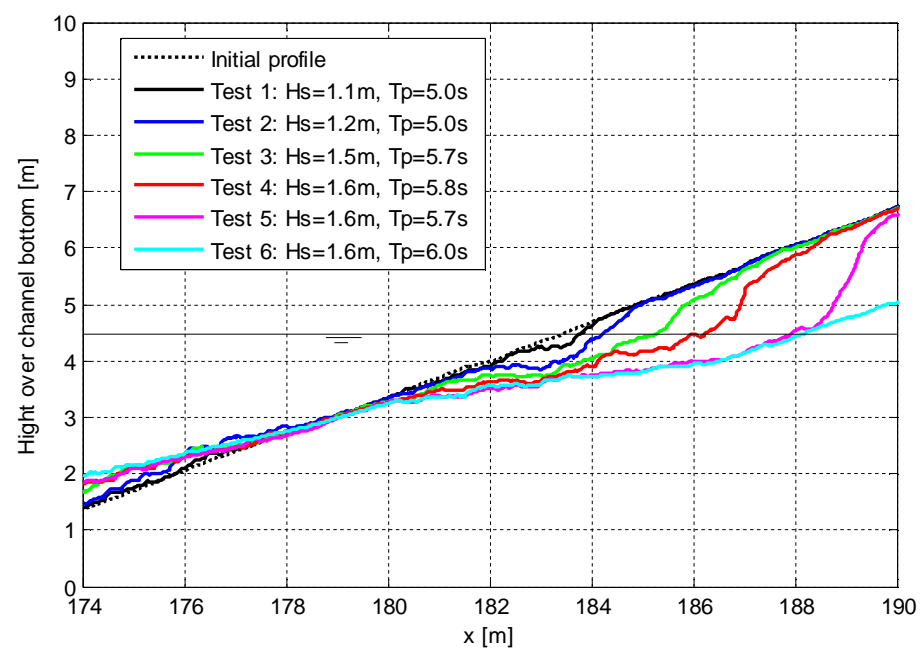

Figure 7. Averaged erosion profiles (vertically averaged over 3 rows, water level $+4.50 \mathrm{~m})$.

\section{Analysis of results}

The erosion profile was found to follow an exponential trend, see Figure 8 .

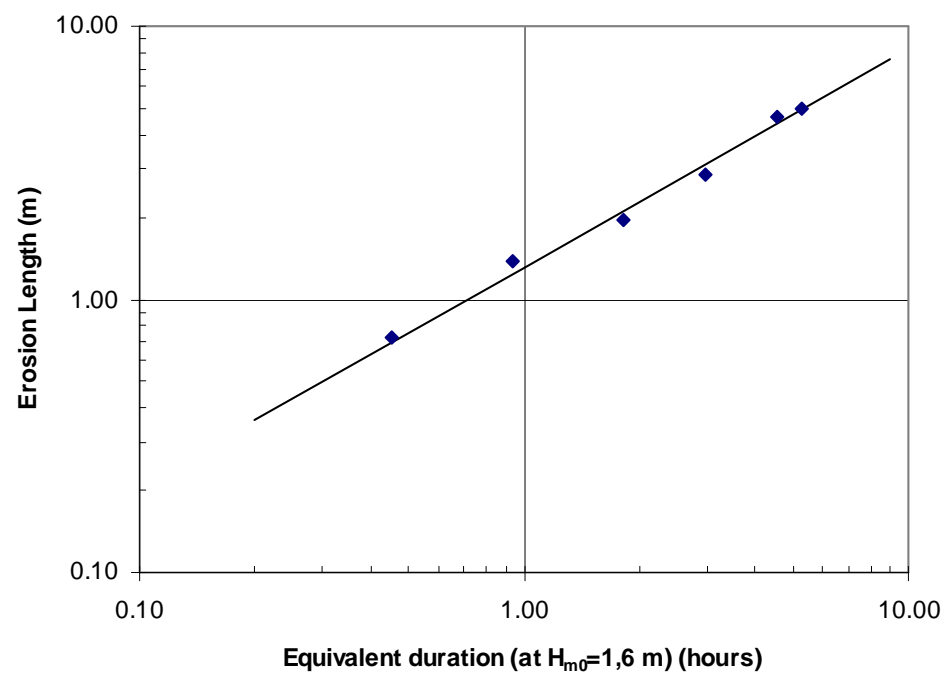

Figure 8. Measured erosion length as function of the cumulative time (recalculated for a constant wave height of $\mathrm{H}_{\mathrm{m} 0}=1.6 \mathrm{~m}$ ) 
Based on the observed exponential trend of the erosion the following formula was developed $\left(\mathrm{R}^{2}=0.98\right)$ :

$$
\frac{E_{x}}{H_{m 0}}=\left(\frac{t}{k}\right)^{0,56}
$$

with: $\mathrm{t}=$ time $[\mathrm{s}], \mathrm{k}=2078.9[\mathrm{~s}], \mathrm{E}_{\mathrm{x}}=\max$. horizontal erosion length $(\mathrm{m})$, significant wave height $\mathrm{H}_{\mathrm{m} 0}[\mathrm{~m}]: 1,1<\mathrm{H}_{\mathrm{m} 0}<1,6 \mathrm{~m}$, slope $1: 3$ and boulder clay as found on the Wieringermeerdijk.

As Figure 8 shows, does the formula provide a good correlation between formula and measurements. A comparison of the formulae from textured clay with the new formula for boulder clay is also given in Figure 9. The employed clay formula is (Delft Hydraulics, 2007):

$$
\frac{E_{x}}{H_{m 0}}=C_{\text {clay }} \cdot(-6,43+\ln t)
$$

with: $\mathrm{t}=$ time $[\mathrm{s}], \mathrm{E}_{\mathrm{x}}=$ horizontal erosion length at $\mathrm{SWL}(\mathrm{m})$,

$$
\mathrm{C}_{\text {clay }}=\text { factor of clay quality } \approx 0,81(-) \text {, textured clay }
$$

The depth above which the erosion is found is approximately $0,9 d_{\text {toe } 2 \%}$, whereby $d_{\text {toe } 2 \%}$ is the depth of the toe of the wave front in relation to SWL, which is exceeded by $2 \%$ of the waves (Delft Hydraulics, 2007):

$$
\frac{d_{t o e 2 \%}}{H_{s}}=\min \left\{0.25+\frac{0.11}{\sqrt{s_{o p}}} ; 2.0\right\}
$$

with: $\mathrm{s}_{\mathrm{op}}=\mathrm{H}_{\mathrm{s}} /\left(1,56 \mathrm{~T}_{\mathrm{p}}{ }^{2}\right)=$ wave steepness $(-)$

Figure 9 shows that in the beginning clay erodes somewhat faster than boulder clay, but with time the erosion velocity becomes much lower than that for boulder clay. Although this trend is generally deemed to be reliable, several factors should however be noted regarding the set-up of the boulder clay tests:

A number of softer boulder clay blocks (as typically found in dikes due to varying boulder clay quality) which were placed above the water level were observed to cause an increase in erosion over time. On the other hand it should be noted that a faster clay erosion in the beginning could be explained by the fact that the top layer is usually textured/fissured or desiccated, which was not 
the case for these boulder clay tests. Beneath the top layer the clay is less textured and the erosive resistance will therefore be higher.

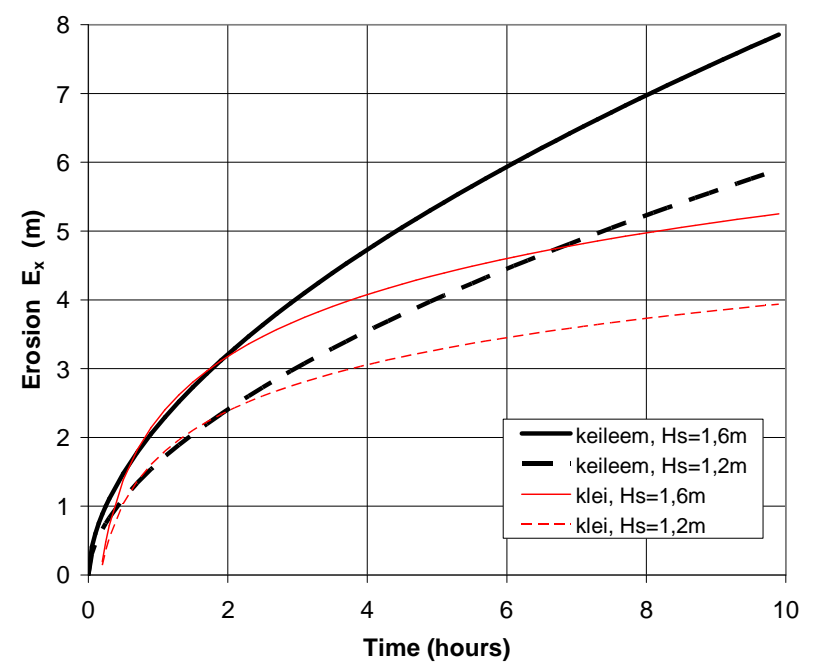

Figure 9. Comparison of measured boulder clay erosion with clay erosion formulae.

It is expected that in reality the erosion on a dike will be lower than measured in the Delta Flume, because:

- The boulder clay has suffered during excavation, transport and placement in the flume, reducing its strength against erosive forces

- The clay at the top of the boulder clay layer showed fissures and began to slide during testing, which might have affected the erosion at the end of the tests.

- The slope under the water level was fixed at 1:3, although in nature it is often shallower.

- The toe was unprotected. An armoured toe is however typical for many clay dikes around the IJsselmeer.

- Only perpendicular wave attack was investigated, although oblique wave attack is more realistic.

The erosion formula as based on these measurements is therefore considered as conservative.

\section{CONCLUSIONS}

Deltares | Delft Hydraulics has conducted an investigation of the erosion resistance of boulder clay, typically employed in dikes within the Netherlands, exposed to wave impact. The study was conducted on behalf of Rijkswaterstaat Noord Holland. The goal was to investigate the (remaining) erosion resistance 
of the boulder clay core if the placed revetment (toplayer of natural pitched stone blocks) has failed. Earlier investigations had indicated that boulder clay has significant erosive strength and could therefore contribute to some extent to the strength of the dike. The tests have been conducted in the Delta Flume of Deltares | Delft Hydraulics at a scale of 1:1.

The following results have been found:

- Boulder clay showed a significant resistance to wave erosion. This erosive strength can be included in future examinations/assessments of dike strength.

- The found erosion was mainly in horizontal direction into the dike (erosion length), which was found to be a better criterium than previously used vertical erosion measures

- The following erosion formula has been found for the investigated boulder clay material and wave conditions (without berm/toe armour protection):

$\frac{E_{x}}{H_{m 0}}=\left(\frac{t}{k}\right)^{0,56}$

with: $\mathrm{t}=$ time [s], $\mathrm{k}=2078.9[\mathrm{~s}], \mathrm{E}_{\mathrm{x}}=$ max. horizontal erosion length (m), significant wave height $\mathrm{H}_{\mathrm{m} 0}[\mathrm{~m}]: 1,1<\mathrm{H}_{\mathrm{m} 0}<1,6 \mathrm{~m}$, slope $1: 3$ and boulder clay as found on the Wieringermeerdijk.

- The largest erosion length was found at $0,1 \mathrm{H}_{\mathrm{m} 0}-0,3 \mathrm{H}_{\mathrm{m} 0}$ beneath $\mathrm{SWL}$.

- The depth above which the erosion is found is approximately $0,9 \mathrm{~d}_{\mathrm{toe} 2} \%$, whereby $d_{\text {toe } 2 \%}$ is the depth of the toe of the wave front in relation to SWL, which is exceeded by $2 \%$ of the waves

- The possible influence of the boulder clay transport, the lack of any toe protection or pavement and the perpendicular wave loading make the results conservative for the investigated dike geometry and wave conditions

- Since in prototype boulder clay characteristics and dike geometries vary, the results are not generally applicable to other materials and dike geometries although they can be used for a first assessment.

- The investigation showed that the behaviour of boulder clay is significantly different from clay. Clay erosion is usually faster at the erosion begin but with time diminishes below that of boulder clay.

\section{ACKNOWLEDGEMENTS}

The presented research project was part of the government research program "Strength \& Loading of Coastal and Inland Water Defences" (RWS 2006). The results of this research were used for the evaluation of the erosive strength of the Wieringermeer dike (Delft Hydraulics, 2008) and will also be 
used for the evaluation of similar dike sections along other parts of the Dutch coastline.

\section{REFERENCES}

Carter, Ch.H. and D.E. Guy. 1988. Coastal erosion: Processes, timing and magnitudes at the bluff toe. Marine geology, 84, 1-17.

Fugro. 2005. Literatuurstudie keileem, rapport 1205-0055-000.

GeoDelft. 2006. Bronnenonderzoek naar erosie en reststerkte van keileem van de Wieringermeerdijk. G. Kruse, Delft, Rapport 419110/610.

Infram. 2005. Kosten/batenanalyse voor de geavanceerde reststerktetoets, Rapport 04i114.

LGM. 1985. Kleionderzoek Deltagootproeven, Provo, CO-416550/4.

RWS. 2006. Sterkte en Belastingen Waterkeringen, projectplan 2007-2 1011, Ministerie van Verkeer en Waterstaat, Rijkswaterstaat, 9 oktober 2006.

Skafel M.G. \& Cr. T. Bishop. 1994. Flume experiments on the erosion of till shores by waves, Coastal Eng. 23, 329-348.

Delft Hydraulics \& GeoDelft. 1993a. Reststerkte van dijkbekledingen. Deel IV, analyse van Deltagootmetingen. Delft Hydraulics. Rapport H195.

Delft Hydraulics \& GeoDelft. 1993b. Reststerkte van dijkbekledingen. Deel III, Meetverslag Deltagootonderzoek. Delft Hydraulics. Rapport H195.

Delft Hydraulics. 2007. Deltagootproeven naar de sterkte van keileem, Report H4739.

Delft Hydraulics. 2008. Reststerkte van de Wieringermeerdijk, Geavanceerde toesting of basis van Deltagootonderzoek, Report H4739.

Zeman A.J. 1986. Erodibility of Lake Erie undisturbed tills, Proc. Symp. Cohesive Shores, Natl. Res. Council Canada, 150-169. 
KEYWORDS - ICCE 2008

LARGE SCALE TESTS OF BOULDER CLAY EROSION AT THE WIERINGERMEER DIKE (IJSSELMEER)

Guido Wolters, Jan-Willem Nieuwenhuis, Jentsje van der Meer and Mark Klein Breteler

Abstract number 608

Dikes

Coastal structures

Boulder clay

Erosion 